\title{
Utilization of Various Data Sources to Locate West Nile Clusters in Tulsa County
}

\author{
Nicole Schlaefli ${ }^{\star 2}$, Kiran Duggirala ${ }^{2}$ and Scott Meador ${ }^{1}$ \\ ${ }^{1}$ Tulsa City-County Health Department, Enviromental Health Program, Tulsa, OK, USA; ${ }^{2}$ Tulsa City-County Health Department, Health, \\ Data, and Evaluation Divison, Tulsa, OK, USA
}

\section{Objective} homa

Identify, analyze, and summarize WNV in Tulsa County, Okla-

\section{Introduction}

As the summer temperatures soared to their highest ever recorded, Oklahoma experienced its highest disease count ever since the disease had been discovered in New York in 1999. Tulsa County is the second most populous county in Oklahoma and accounted for over onefourth of the West Nile Cases in Oklahoma. Tulsa City County Health Department is also the only funded mosquito control program in the state that regularly reports to CDC's AborNet.

\section{Methods}

As part of the mosquito surveillance program run by TCCHD's Environmental Health Program, 75 mosquito traps are placed around the county. The traps are tested once a week during the season which runs May to November. The areas that the traps are located in are then sprayed with mosquito repellent. The EHP also gathers addresses of the West Nile positive persons that are reported to the Epidemiology Department. The positive trap locations and the human case addresses are then mapped onto a geographic representation map of Tulsa County using ArcGIS ArcMap 10.0 software.Historical trend analysis data of past West Nile cases by year, age, location and climate are then compared to the current year.

\section{Results}

From interviews conducted with West Nile positive human cases, the majority of cases reported the likelihood of being bitten on their property. Once the human case locations were overlaid with positive trap locations and a map of the storm drain system in Tulsa County, clusters formed and areas that needed to be sprayed were identified.

\section{Conclusions}

Recommendations are made throughout the season to community officials based on analysis and results found. Lessons learned from the outbreak response conducted included:

Addition of larvacidal treatment of Tulsa County Storm drainage system ods

Aggressive marketing campaign in regards to prevention meth-

Purpose and role of Long Term Acute Care centers in regards to human recovery

Proposed creation of a West Nile Survivors Group

West Nile Virus Disease

\begin{tabular}{|c|c|c|c|c|c|c|c|c|}
\hline & $\begin{array}{c}\text { Mosquito } \\
\text { Traps }\end{array}$ & $\begin{array}{c}\text { Positive } \\
\text { Mosquito } \\
\text { Traps (\%) }\end{array}$ & $\begin{array}{c}\text { WNV } \\
\text { Fever }\end{array}$ & $\begin{array}{c}\text { WNV } \\
\text { Neuroinvasive }\end{array}$ & $\begin{array}{c}\text { Total \# } \\
\text { Rate per } \\
100,000)\end{array}$ & $\begin{array}{c}\text { Hospitalizations } \\
\text { Due to WNV }\end{array}$ & $\begin{array}{c}\text { Deaths } \\
\text { Due to } \\
\text { WNV }\end{array}$ & $\begin{array}{c}\text { WNV } \\
\text { Blood } \\
\text { Donors }\end{array}$ \\
\hline Oklahoma & & & 47 & 71 & $118(3.1)$ & 74 & 7 & 35 \\
\hline $\begin{array}{c}\text { Tulsa } \\
\text { County }\end{array}$ & 75 & $55(73 \%)$ & 8 & 21 & $29(4.8)$ & 16 & 2 & 6 \\
\hline
\end{tabular}

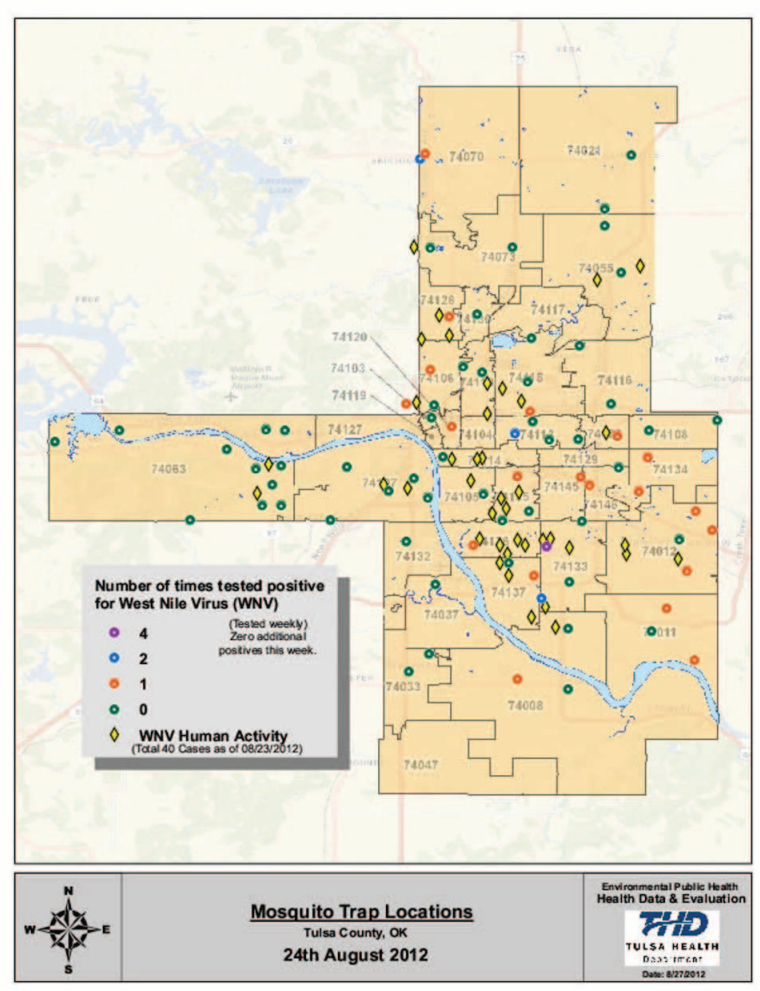

Keywords

Surveillance; West Nile; Mosquito

\section{Acknowledgments}

Christie McDonald-Hamm, MPH; Surveillance Officer, Department of Informatics; Oklahoma State Department of Health

\section{References}

Tulsa County, Oklahoma Public Works Department

Public Health Investigation of Disease Database in Oklahoma (PHIDDO) Mosquito Database, Environmental Health Program, Tulsa City County Health Department

http://www.cdc.gov/ncdod/dvbid/westnile/index.htm Centers for Disease Control and Prevention, U.S. Environmental Protection Agency, National Oceanic and Atmospheric Agency, and American Water Works Association. 2010. When every drop counts: protecting public health during drought conditions - a guide for public health professionals. Atlanta: U.S. Department of Health and Human Services.

*Nicole Schlaefli

E-mail: nschlaefli@tulsa-health.org 